\title{
EXPERIMENTAL ANALYSIS OF DENTAL-IMPLANT LOAD TRANSFER IN POLYMETHYL-METHACRYLATE BLOCKS
}

\author{
EKSPERIMENTALNA ANALIZA PRENOSA OBREMENITVE Z \\ ZOBNIH VSADKOV NA POLIMETIL-METAKRILATNE BLOKE
}

\author{
Dusan Sarac ${ }^{1}$, Nenad Mitrovic ${ }^{1}$, Ivan Tanasic ${ }^{2}$, Zarko Miskovic ${ }^{1}$, Ljiljana Tihacek-Sojic ${ }^{3}$ \\ ${ }^{1}$ University of Belgrade, Faculty of Mechanical Engineering, 11000 Belgrade, Serbia \\ 2 Medical Health Center, Vojvode Misica 231, Obrenovac, 11000 Belgrade, Serbia \\ ${ }^{3}$ University of Belgrade, School of Dentistry, Clinic of Prosthodontics, 11000 Belgrade, Serbia
}

Prejem rokopisa - received: 2018-04-23; sprejem za objavo - accepted for publication: 2018-10-18

\section{doi:10.17222/mit.2018.081}

\begin{abstract}
Dental-implant overload can cause bone resorption. Load-transfer characteristics of dental implants are affected by their macro-design parameters. The goal of this study was to experimentally analyse the load-transfer characteristics of different dental implants, using polymethyl-methacrylate blocks. Three polymethyl-methacrylate blocks were created, with dimensions of $(68 \times 25 \times 9) \mathrm{mm}$. Three dental implants, Nobel $\varnothing 3.5 \mathrm{~mm} \times 15 \mathrm{~mm}$, Strauman $\varnothing 4.1 \mathrm{~mm} \times 10 \mathrm{~mm}$ and Strauman $\varnothing 4.8 \mathrm{~mm} \times$ $12 \mathrm{~mm}$, were placed in separate blocks. The samples were supported by a three-point-bending set-up and loaded with an axial force of $600 \mathrm{~N}$. The 3D digital image correlation method was employed for strain and displacement measurements. The highest displacement and von Mises strain values were found for Strauman $\varnothing 4.1 \mathrm{~mm} \times 10 \mathrm{~mm}(p<0.05), 0.186 \mathrm{~mm}$ and $0.596 \%$, respectively. The sample of Nobel $\varnothing 3.5 \mathrm{~mm} \times 15 \mathrm{~mm}$ showed the lowest strain values. The sample of Strauman $\varnothing 4.8 \mathrm{~mm} \times 12$ $\mathrm{mm}(p>0.05)$ had similar strain values as Nobel $\varnothing 3.5 \mathrm{~mm} \times 15 \mathrm{~mm}$. The load transfer during axial loading was primarily affected by the size of the implant contact surface. The displacement and strain values in the implant vicinity may provide an insight into the effect of dental-implant design on the load transfer.

Keywords: dental implant, digital image correlation, polymethyl-methacrylate, load transfer
\end{abstract}

Preobremenitev zobnih vsadkov lahko povzroči resorpcijo kosti. Zaradi prenosa obremenitve je karakteristika zobnih vsadkov odvisna od njihovih mikroparametrov oblikovanja. Cilj predstavljene študije je bila eksperimentalna analiza karakteristik prenosa obremenitve različnih zobnih vsadkov z uporabo polimetil-metakrilatnih blokov. Avtorji so izdelali tri polimetil-metakrilatne bloke dimenzij $(68 \times 25 \times 9) \mathrm{mm}$. Tri dentalne vsadke, Nobel $\varnothing 3,5 \times 15 \mathrm{~mm}$, Strauman $\emptyset 4,1 \times 10 \mathrm{~mm}$ in Strauman $\varnothing 4,8 \times 12 \mathrm{~mm}$, so namestili v posamezne bloke. Vzorce so nato podprli s tritočkovno upogibno napravo in jih obremenili z osno silo $600 \mathrm{~N}$. Za merjenje deformacije in pomikov so uporabili 3D digitalno slikovno korelacijo. Največji odmik in von Misesovo deformacijo so izmerili pri vsadku Strauman $\emptyset 4,1 \times 10 \mathrm{~mm}(\mathrm{p}<0,05), 0,186 \mathrm{~mm}$ in $0,596 \%$. Pri vzorcu Nobel $\emptyset 3,5 \times 15 \mathrm{~mm}$ so ugotovili najmanjše deformacije. Vzorec Strauman $\varnothing 4,8 \times 12 \mathrm{~mm}(\mathrm{p}>0,05)$ je imel podobne vrednosti deformacije kot Nobel $\emptyset 3,5 \times 15 \mathrm{~mm}$. Prenos obremenitve med osnim obremenjevanjem je bil odvisen predvsem od velikosti kontaktne površine vsadka. Premiki in deformacije v bližini vsadkov lahko zagotavljajo vpogled v oblikovanje zobnih vsadkov glede na prenos obremenitve.

Ključne besede: zobni vsadki, korelacija z digitalno sliko, polimetil-metakrilat, prenos obremenitve

\section{INTRODUCTION}

Dental-implant overload can cause bone resorption and implant failure. ${ }^{1,2}$ It is known that dental-implant micro-design has a considerable influence on the load transfer and therefore on the bone resorption and remodelling. ${ }^{3}$ As a result of continuous research and consumer demand, implant design has been changed. ${ }^{2}$ Studies with the goal to resolve the effect of dentalimplant geometry on the load transfer primarily used numerical techniques. ${ }^{2,4} \mathrm{~A}$ numerical analysis relies on the assumptions concerning the implant geometry, material characteristics and boundary conditions. Therefore, the numerical analysis needs to be verified with experimental data. Nevertheless, it can provide a great insight into and a solution to various problems encountered in dental practice or elsewhere. Dental-implant geometrical

*Corresponding author e-mail:

dsarac@mas.bg.ac.rs characteristics can be divided into micro- and macrodesign. The micro-design refers to the surface roughness, while the macro-design refers to the characteristics such as diameter, length, shape and thread (pitch, depth and profile). The implant diameter is often described as the most important factor when the load transfer of a dental implant is concerned. ${ }^{5}$ The length and thread are also considered important, but are still of the secondary influence compared to the implant diameter. ${ }^{5}$ Over 1300 different dental implant types can be found on the market. ${ }^{6}$ There is no consensus regarding the best dental implant design. ${ }^{7}$ Different acrylate models were used to analyse the load transfer of implant-supported prostheses and crown materials. ${ }^{8,9}$ It is reported that the strain measured on the surface of interest can reflect the implant or prosthesis design. ${ }^{8}$ The aim of this study is to employ an experimental acrylate block model and the 3D digital image correlation (DIC) technique to analyse the effects of dental-implant macro-design parameters on the 
displacement and strain fields in the vicinity of an implant during an axial load. DIC can help us determine a full-field strain and displacements with an accuracy of $0.01 \% .^{8}$ An additional goal was to explore the possibility of using similar models and procedures with larger groups of dental implants that are already used in dental practice.

\section{EXPERIMENTAL PART}

Three different dental implants were used in this study: NobelSpeadyReplace $\varnothing 3.5 \mathrm{~mm} \times 15 \mathrm{~mm}$, Strauman $\varnothing 4.1 \mathrm{~mm} \times 10 \mathrm{~mm}$ and Strauman $\varnothing 4.8 \mathrm{~mm} \times 12 \mathrm{~mm}$ (Figure 1). Models of three moulds with interior dimensions of $(68 \times 25 \times 9) \mathrm{mm}$ were created using software SolidWorks (Dassault Systems, USA). The physical models of the moulds were manufactured using Ultimaker 2+ 3D printers (Ultimaker, Netherlands). Polylactic acid (PLA) plastic was used as the 3D printing material. Every mould had a specific groove on the topside, which corresponded to the implant neck. In this way, every implant could be fixed in the vertical position during the process of block casting (Figure 2).

Prior to the PMMA infill, the interior of the moulds was coated with a thin layer of medical vaseline in order to prevent PMMA from melting the mould due to its exothermic polymerization effect. This step also allowed an easier extraction after the hardening.

Afterwards, liquid PMMA (Triplex Cold, Vivoclar, Lichtenstein) was poured into the mould openings. The polymerization lasted for $15 \mathrm{~min}$ at a constant temperature of $40{ }^{\circ} \mathrm{C}$ in a UN 30 (Memmert, Germany) heating oven. Hardened samples were removed from the mould and marked as N1, S1 and S2 (Table 1). The surface of interest was painted with a layer of white paint and afterwards a stochastic layer of black dots was added (Figure 2). The samples were placed on the custom-made holder of the three-point-bending configuration (Figure 3). A span length of $48 \mathrm{~mm}$ was used in order to mimic a half arch of the jaw. ${ }^{8}$ The strain field and displacement were measured using 3D optical system Aramis 2M (GOM, Braunschweig, Germany). The digital image correlation method is an optical contactless technique for measuring the full-field strain and displacement. ${ }^{10}$ The speckle

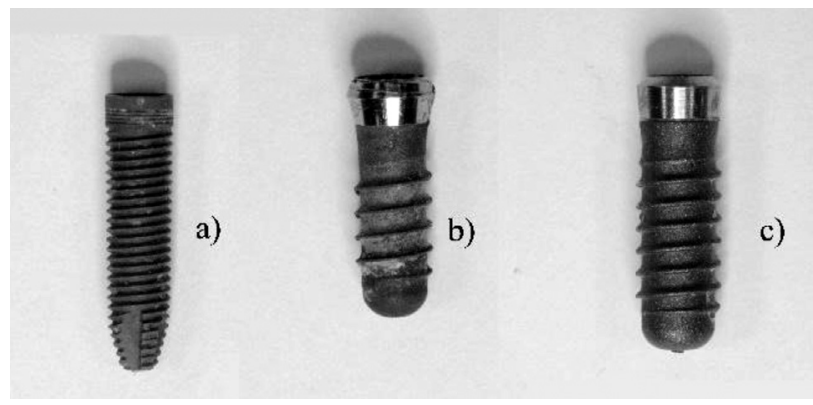

Figure 1: Dental implants: a) Nobel $\emptyset 3.5 \mathrm{~mm} \times 15 \mathrm{~mm}$, b) Strauman $\emptyset 4.1 \mathrm{~mm} \times 10 \mathrm{~mm}, \mathrm{c})$ Strauman $\varnothing 4.8 \mathrm{~mm} \times 12 \mathrm{~mm}$

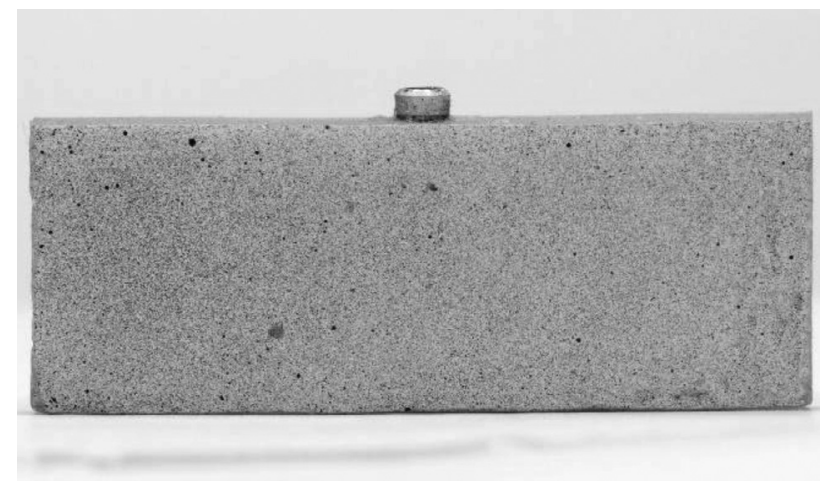

Figure 2: Sample surface with a stochastic pattern (sample S2)

Table 1: Sample details

\begin{tabular}{|c|c|c|}
\hline $\begin{array}{c}\text { Sample name } \\
\text { reference }\end{array}$ & $\begin{array}{c}\text { Implant dimensions } \\
(\mathrm{mm})\end{array}$ & Manufacturer \\
\hline $\mathrm{N} 1$ & $\varnothing 3.5 \times 15$ & Nobel Biocare \\
\hline $\mathrm{S} 1$ & $\varnothing 4.1 \times 10$ & Strauman \\
\hline $\mathrm{S} 2$ & $\varnothing 4.8 \times 12$ & Strauman \\
\hline
\end{tabular}

pattern enabled the 3D DIC system to measure the displacement and strain on the sample surface of interest. For a uniform illumination, a white light source was used. A system calibration was performed according to the manufacturer's instructions.

An axial load of $600 \mathrm{~N}$ was applied onto the top of the implant using an H10K-s universal testing machine (Tinius Olsen, USA). All implants were loaded without an abutment. Integrated travel measurement system positioning was done automatically, limiting the contact force with the dental implant to a value below $0.5 \mathrm{~N}$. Every subsequent image was made after a $50-\mathrm{N}$ force increase. During the loading stages, series of consecutive images were created. The load was considered static. After reaching the maximum force of $600 \mathrm{~N}$, the model was unloaded and one additional image of the sample was created. After the measurements, the images were exported into the Aramis v6.2.0 (GOM, Germany) software. A statistical analysis and data graphical representation were performed in software R (Vienna, Austria).

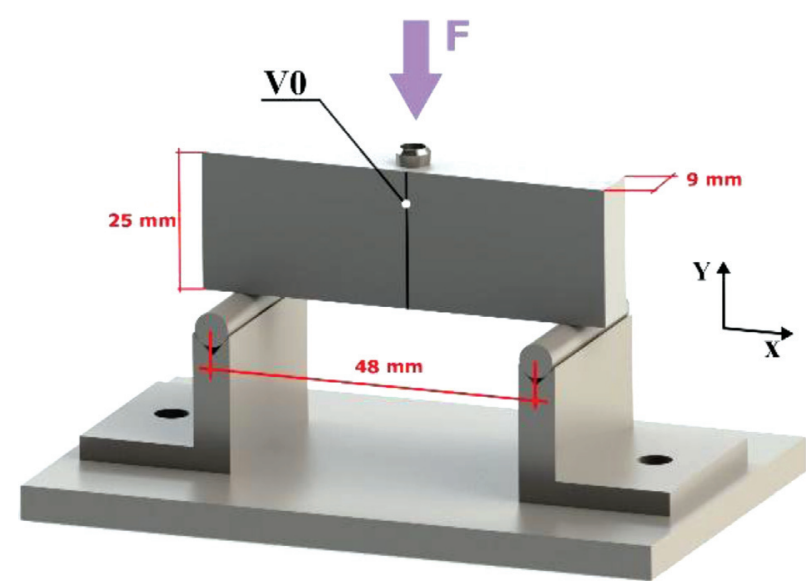

Figure 3: Scheme of the experimental set-up 


\section{RESULTS}

Results were presented in the form of displacement $\mathrm{Y}$ and von Mises strain. However, quantitative differences remained, so section V0 was placed on the sample surfaces, along the longitudinal axis of dental implants (Figure 3), and data was presented in the form of tables and comparative diagrams for all the samples. The displacement and strain values used in the statistical analysis were extracted from the measurement points along section V0.

Displacement $\mathrm{Y}$ for all three samples is presented in Figure 7. Displacement values were negative as the vertical y axis was directed upwards (Figure 4). The results showed that displacement values varied between the samples. Sample N1 showed the lowest displacement

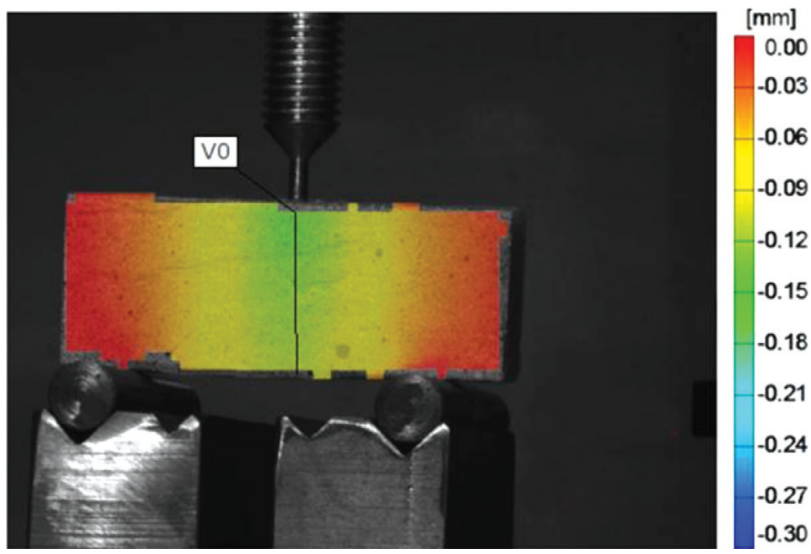

Figure 4: Displacement field on the N1 sample surface

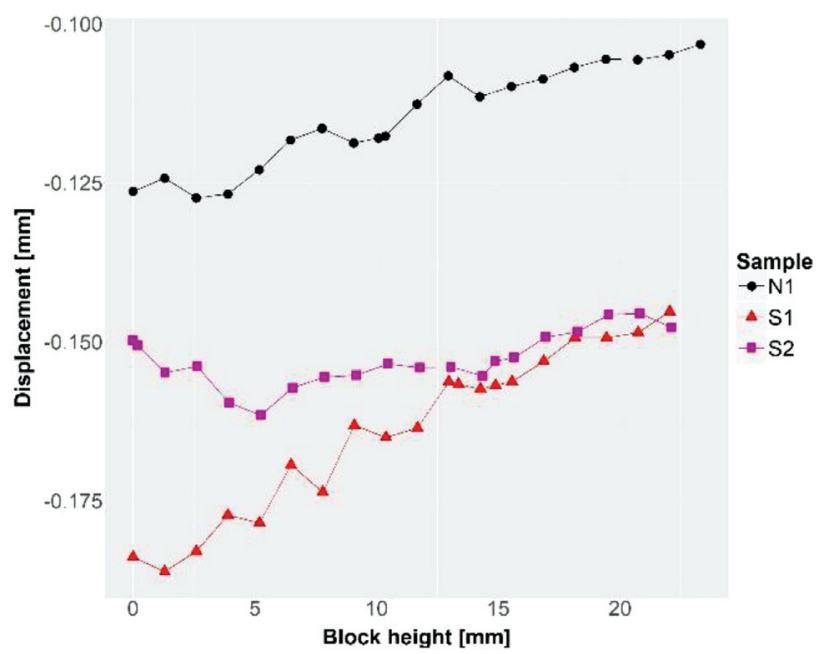

Figure 5: Displacements on section V0 for all the samples

Table 2: Vertical displacements along section V0

\begin{tabular}{|c|c|c|c|}
\hline & \multicolumn{3}{|c|}{ Displacement $(\mathrm{mm})$} \\
\hline Sample & Mean & SD & Max \\
\hline N1 & -0.11 & 0.01 & -0.127 \\
\hline S1 & -0.16 & 0.01 & -0.186 \\
\hline S2 & -0.15 & 0.00 & -0.162 \\
\hline
\end{tabular}

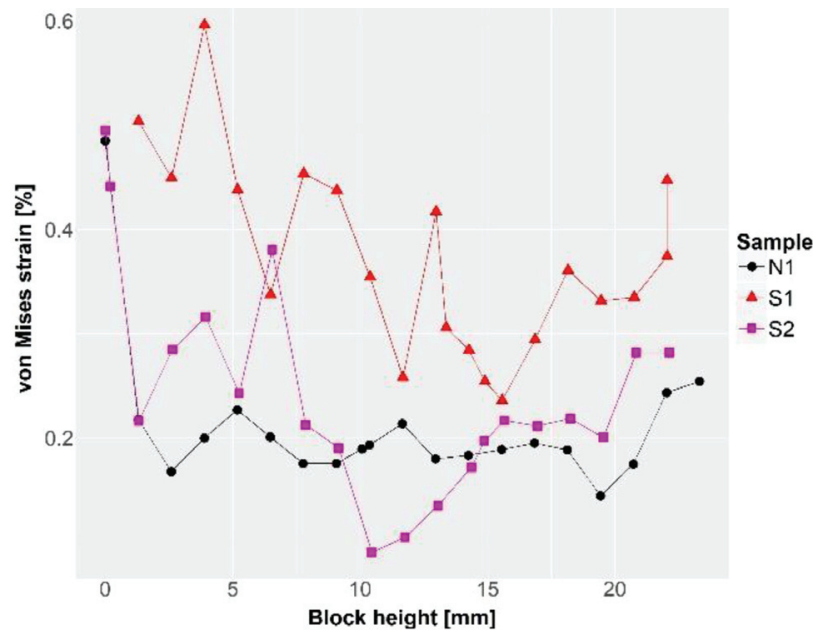

Figure 6: Von Mises strain values on section V0 for all the samples

Table 3: Von Mises strain values along section V0

\begin{tabular}{|c|c|c|c|}
\hline & \multicolumn{3}{|c|}{ Mises strain (\%) } \\
\hline Sample & Mean & SD & Max \\
\hline N1 & 0.21 & 0.07 & 0.485 \\
\hline S1 & 0.37 & 0.09 & 0.596 \\
\hline S2 & 0.24 & 0.10 & 0.495 \\
\hline
\end{tabular}

values, while sample S1 had the highest values. The highest displacement values were generally located on the block surface, at the marginal level of an implant.

A similar trend was observed for the von Mises strain values (Figure 8). The highest strain value was found at the implant neck level, in a range of $0.4-0.6 \%$, depending on the sample. The maximum and mean values, as well as the standard deviation values of displacement $\mathrm{Y}$ and von Mises strain are presented in Tables $\mathbf{2}$ and $\mathbf{3}$.

The results were further imported into the $\mathrm{R}$ software for a statistical analysis. Significant differences in the displacement values along the block height were found between all three samples, using one-way ANOVA. The Tukey post-hoc test revealed significant differences ( $p=$ 0.000 ) between the displacement values for all three samples (Table 4).

Table 4: p-values for displacement and von Mises strain

\begin{tabular}{|c|c|c|}
\hline & \multicolumn{2}{|c|}{$\mathrm{p}$-Value } \\
\hline Sample & Displacement & Mises \\
\hline N1-S1 & 0.00 & 0.00 \\
\hline N1-S2 & 0.00 & 0.41 \\
\hline S1-S2 & 0.01 & 0.00 \\
\hline
\end{tabular}

Similarly, von Mises strain values were also compared. Significant differences were found between all the sample combinations $(p=0.000)$, except for N1 and S2 $(p=0.41)$ (Table 4). 


\section{DISCUSSION}

In this study, 3D digital image correlation was applied in order to compare the displacement and von Mises strain in the vicinity of three different dental implants. This method enables a non-contact measurement of displacement and strain values. It is independent of the model material, thus overcoming the obstacle of creating bone models from the materials with birefractive properties, whose behaviour may not be similar to that of the bone.

The influence of the dental-implant design was the subject of many papers, which usually applied numerical methods to analyse the problem. In experimental studies, photoelastic methods and strain gauges were mostly used. ${ }^{11}$ Both techniques have some limitations. Strain gauges provide localized measurements, while the photoelastic technique provides only qualitative data and requires an application of birefractive materials. There is only a limited number of experimental studies that compare dental-implant designs. Pellizzer et al. compared five different dental-implant designs using photoelastic models. ${ }^{1}$ They reported that the presence of a specific thread type affects the load transfer and stress on the contact surface, although the parameters like implant diameter and length were not commented on. A similar analysis was conducted by Cehreli et al. ${ }^{9}$ Through experimental results, they concluded that a greater implant diameter contributes to a lower stress and strain in the block model in the vicinity of an implant.

The most obvious differences between samples N1 and S2 were found in the diameter and length. The diameter of the sample-S2 implant was $27 \%$ larger and it was $20 \%$ shorter. The implant diameter was shown to be the primary parameter of influence when the load transfer was taken into consideration. ${ }^{12}$

On the surfaces of interest, differences in the axial displacement and von Mises strain values were observed between the samples. Nobel $\varnothing 3.5 \mathrm{~mm} \times 15 \mathrm{~mm}$ (in N1) showed the lowest displacement and strain values, while the highest values were observed for Strauman $\varnothing 4.1 \mathrm{~mm}$ $\times 10 \mathrm{~mm}(\mathrm{~S} 1)$. The vertical displacement seemed to be more affected by the implant length and the thread characteristics or by their combined effect in the form of a greater contact surface. The thread pitch was the smallest for the N1 implant, which entailed the highest thread density and a greater contact surface than those of the Strauman implants. These conditions caused reduced displacement and strain values. The implant contact surface is one of the main parameters, affecting the values of stress and strain in its vicinity. Additionally, the N1 implant neck exhibited micro-threads that bonded better with the crestal bone and transformed the shear load into compression. This presents an advantage because the bone and PMMA should be loaded in compression whenever possible. ${ }^{13}$ This feature is also found to promote the bone formation in the crestal area. ${ }^{14} \mathrm{In}$ this case, this feature is not as significant as when found in a bone due to the bone's ability to osseointegrate. Nevertheless, it seems that the presence of microthreads leads to a better bonding with the acrylate block when compared with a strictly rough surface.

A similar result was reported for photoelastic models where the highest strain was found in the cervical third of the block..$^{1,15}$ It was not observed that the diameter size played a crucial role during the loading process. Numerous studies reported that the implant diameter was the most notable when lateral loads were applied. ${ }^{16,17}$ But the strain patterns for the axial and lateral loading are different. ${ }^{5}$ During the axial loading, the implant length is considered to be more important, especially in a cancellous bone. ${ }^{16}$ Although this model was not made of a cancellous bone, its modulus of elasticity was $2 \mathrm{GPa}$, which was close to the cancellous modulus of elasticity that is around $1.4 \mathrm{GPa}^{18}$ This difference is less notable when compared with the cortical bone elasticity modulus $(14 \mathrm{GPa}){ }^{18}$ Although no abutments were attached to the implants, it was reported that during the axial loading, the load transfer was very similar to these two cases, but only when an axial load was applied. ${ }^{15}$

The acquired results lead to the same conclusion. When determining the optimal design of dental implants, the values of mechanical strain and stress can point toward the most important parameters. Sometimes the parameters like implant diameter, length, shape, surface and thread should not be evaluated only individually as their combined effect should be examined as well. This simplified jaw-bone model can be applied to many dental implants available on the market. ${ }^{6}$ The results found on the surface of interest reflect the effects of dental-implant design and loading conditions. This model can provide an additional insight into the biomechanical influence of dental-implant design on the load-transfer characteristics.

\section{CONCLUSIONS}

The goal of this study was to evaluate the load transfer of dental implants under an axial load onto the surrounding structure. The implant length in combination with a large contact surface can provide a more optimal load transfer during the axial loading. Acrylate models can be applied to different implant types to experimentally detect and compare the effects of implant geometries on the surrounding area. A combined effect of geometrical parameters should also be taken into consideration. Future research should explore the application of lateral loads in similar settings.

\section{Acknowledgement}

This research was supported by the Ministry of Education, Science and Technological Development of the Republic of Serbia within Projects TR35031, 
TR35040, III41006 and III45009, which we gratefully acknowledge.

\section{REFERENCES}

${ }^{1}$ E. P. Pellizzer, R. I. Carli, R. M. Falcón-Antenucci, F. R. Verri, M. C. Goiato, L. M. R. Villa, Photoelastic analysis of stress distribution with different implant systems, J. Oral Implantol., 40 (2014) 2, 117-122, doi:10.1563/AAID-JOI-D-11-00138

${ }^{2}$ J. L. Zheng Li, Jingsong Yang, Xuefeng Hu, Three dimensional finite element analysis of a novel osteointegrated dental implant designed to reduce stress peak of cortical bone, Acta Bioeng. Biomech., 16 (2014) 3, 21-28, doi:10.5277/abb140303

${ }^{3}$ J. Ao, T. Li, Y. Liu, Y. Ding, G. Wu, K. Hu, L. Kong, Optimal design of thread height and width on an immediately loaded cylinder implant: A finite element analysis, Comput. Biol. Med., 40 (2010) 8, 681-686, doi:10.1016/j.compbiomed.2009.10.007

${ }^{4}$ D. A. de Faria Almeida, E. P. Pellizzer, F. R. Verri, J. F. Santiago, P. S. P. de Carvalho, Influence of tapered and external hexagon connections on bone stresses around tilted dental implants: threedimensional finite element method with statistical analysis, J. Periodontol., 85 (2014) 2, 261-9, doi:10.1902/jop.2013.120713

${ }^{5}$ X. Ding, S. H. Liao, X. H. Zhu, X. H. Zhang, L. Zhang, Effect of diameter and length on stress distribution of the alveolar crest around immediate loading implants, Clin. Implant Dent. Relat. Res., 11 (2009) 4, 279-287, doi:10.1111/j.1708-8208.2008.00124.x

${ }^{6}$ M. Esposito, L. Murray-Curtis, M. G. Grusovin, P. Coulthard, H. V. Worthington, Interventions for replacing missing teeth: different types of dental implants, Cochrane Database Syst. Rev., (2014) 4, CD003815, doi:10.1002/14651858.CD003815.pub4

${ }^{7}$ B. Ali, O. E. B. Chuikh, M. H. Meddah, A. Merdji, B. A. B. Bouiadjra, Effects of overloading in mastication on the mechanical behaviour of dental implants, Mater. Des., 47 (2013) 210-217, doi:10.1016/j.matdes.2012.12.019

${ }^{8}$ R. Tiossi, L. Lin, H. J. Conrad, R. C. S. Rodrigues, Y. C. Heo, M. D G. C. de Mattos, A. S.-L. Fok, R. F. Ribeiro, Digital image correlation analysis on the influence of crown material in implantsupported prostheses on bone strain distribution, J. Prosthodont. Res., 56 (2012) 1, 25-31, doi:10.1016/j.jpor.2011.05.003

${ }^{9}$ M. Cehreli, J. Duyck, M. De Cooman, R. Puers, I. Naert, Implant design and interface force transfer: A photoelastic and strain-gauge analysis, Clin. Oral Implants Res., 15 (2004) 2, 249-257, doi:10.1111/j.1600-0501.2004.00979.x

${ }^{10}$ N. Mitrovic, M. Milosevic, A. Sedmak, A. Petrovic, R. Prokic-Cvetkovic, Application and mode of operation of non-contact stereometric measuring system of biomaterials, FME Trans., 39 (2011) 2, 55-60

${ }^{11}$ C. Hekimoglu, N. Anil, M. C. Cehreli, Analysis of strain around endosseous dental implants opposing natural teeth or implants, J. Prosthet. Dent., 92 (2004) 5, 441-6, doi:10.1016/ S0022391304004895

${ }^{12}$ N. Kang, Y.-Y. Wu, P. Gong, L. Yue, G.-M. Ou, A study of force distribution of loading stresses on implant-bone interface on short implant length using 3-dimensional finite element analysis, Oral Surg. Oral Med. Oral Pathol. Oral Radiol., 118 (2014) 5, 519-23, doi:10.1016/j.oooo.2014.05.021

${ }^{13}$ C. Lee, Properties of Bone Cement: the mechanical properties of PMMA bone cement, The Well-Cemented Total Hip Arthroplasty, 2005, 60-66, doi:10.1007/3-540-28924-0_6

${ }^{14}$ H.-S. Ryu, C. Namgung, J.-H. Lee, Y.-J. Lim, The influence of thread geometry on implant osseointegration under immediate loading: a literature review, J. Adv. Prosthodont., 6 (2014) 6, 547-54, doi:10.4047/jap.2014.6.6.547

${ }^{15}$ B. R. Merz, S. Hunenbart, U. C. Belser, Mechanics of the implantabutment connection: an 8-degree taper compared to a butt joint connection, Int. J. Oral Maxillofac. Implants, 15 (2000) 4, 519-26

${ }^{16}$ T. Li, K. Hu, L. Cheng, Y. Ding, Y. Ding, J. Shao, L. Kong, Optimum selection of the dental implant diameter and length in the posterior mandible with poor bone quality - A 3D finite element analysis, Appl. Math. Model., 35 (2011) 1, 446-456, doi:10.1016/j.apm. 2010.07.008

${ }^{17}$ S. H. Chang, C. L. Lin, S. S. Hsue, Y. S. Lin, S. R. Huang, Biomechanical analysis of the effects of implant diameter and bone quality in short implants placed in the atrophic posterior maxilla, Med. Eng. Phys., 34 (2012) 2, 153-160, doi:10.1016/j.medengphy. 2011.07.005

${ }^{18}$ A. Merdji, B. Bachir Bouiadjra, B. Ould Chikh, R. Mootanah, L. Aminallah, B. Serier, I. M. Muslih, Stress distribution in dental prosthesis under an occlusal combined dynamic loading, Mater. Des., 36 (2012) 705-713, doi:10.1016/j.matdes.2011.12.006 